\title{
Studi Etnobotani Pemanfaatan Tanaman Sayuran di Kabupaten Pamekasan
}

\author{
Eko Setiawan \\ Prodi Agroekoteknologi, Fakultas Pertanian, Universitas Trunojoyo Madura \\ e_setiawan@trunojoyo.ac.id
}

Ethnobotanical Study on Utilization of Vegetable Crops in Pamekasan District

\begin{abstract}
Indigenous vegetables have become popular, but the information of crops cultivated by farmers is limited. The objective of this research was to investigate the crops cultural of indigenous vegetables by farmers and their uses in Pamekasan district, East Java, Indonesia during rainy season, December of 2016. In depth observations of the indigenous vegetables and interviews with farmers were conducted in six sub-districts, i.e., Pasean (50 $\mathrm{m}$ above the sea level; asl), Waru (159 $\mathrm{m}$ asl), Pakong (250 $\mathrm{m}$ asl), Kadur (140 $\mathrm{m}$ asl), Pademawu (7 $\mathrm{m}$ asl) and Tlanakan (22 $\mathrm{m}$ asl). This study showed that utilization of the indigenous vegetables in Pamekasan district is still varied and not yet maximal. Vegetable crop has been highest utilities by the society in Waru Sub-district (50\%), Tlanakan Subdistrict (47.1\%) and Pademawu Sub-district (42.1\%), while the vegetables utilization has not been maximal in Kecamatan Kadur (53.3\%), Pakong Sub-district and Pasean Sub-district (50\%). The most un-utilities vegetables are in Kecamatan Pakong (22.2\%) and Pasean sub-districts (20\%).
\end{abstract}

Keywords: cultivated, Pamekasan dsctrict, indigenus vegetables, 


\section{PENDAHULUAN}

Indonesia

keanekaragaman

kaya akan tanaman, diantaranya Sayuran indigenous saat ini masih dilupakan oleh masyarakat Indonesia diantaranya genjer (Limnocharis flava (L.) Buchenau), kenikir (Cosmos caudatus Kunth.), leunca (Solanum americanum Miller) dan poh-pohan (Pilea melastomoides (Poir.) Wedd.) (Santosa et al., 2015), saat ini popularitasnya mulai meningkat. Sayuran indigenous merupakan sayuran asli daerah yang telah banyak diusahakan dan dikonsumsi sejak zaman dahulu, atau sayuran introduksi yang telah berkembang lama dan dikenal masyarakat di suatu daerah tertentu dan dijual di pasar lokal (Santosa et al., 2015).

Tingkat konsumsi sayuran penduduk Indonesia masih rendah, dibawah standar konsumsi sayur yang direkomendasikan oleh FAO sebanyak $73 \mathrm{~kg} / \mathrm{kapita} / \mathrm{tahun}$, sedangkan standar kecukupan untuk sehat sebanyak 91.25 $\mathrm{kg} / \mathrm{kapita} / \mathrm{tahun}$. Rendahnya konsumsi masyarakat Indonesia terhadap sayuran termasuk di Kabupaten Pamekasan. Hal tersebut dapat disebabkan oleh kurangnya pengetahuan masyarakat tentang jenis-jenis tanaman yang dapat dimanfaatkan sebagai sayur untuk dikonsumsi.

Kabupaten Pamekasan merupakan salah satu kabupaten yang ada di pulau Madura, memiliki luas wilayah 79230 ha. Secara geografis wilayah kabupaten Pamekasan terletak pada $113^{\circ} 09^{\prime}$ 113058' Bujur Timur dan 0651'$07^{\circ} 31^{\prime}$ Lintang Selatan. Wilayah Kabupaten Pamekasan terbagi menjadi 13 kecamatan yakni Kecamatan Batumarmar, Pasean, Waru, Pakong, Kadur, Pegantenan, Palengaan, Pamekasan, Larangan,
Galis, Pademawu, Tlanakan. Kabupaten Pamekasan berada pada ketinggian 6 sampai 350 mdpl. Wilayah Kabupaten Pamekasan terdiri dari jenis tanah regosol seluas $36063 \mathrm{ha}$, tanah jenis litosol dengan luas 19084 hektar dan tanah dengan jenis mediteran seluas 17375 ha serta 6708 ha berjenis tanah alluvial. Sekitar 76\% wilayah Kabupaten Pamekasan berada pada kemiringan di bawah 15\%, wilayah dengan kemiringan $15-25^{\circ}$ sekitar $18 \%$ dan $6 \%$ sisanya berada pada kemiringan diatas 25으 (BPS Pamekasan, 2015).

\section{METODE PENELITIAN}

Eksplorasi dilakukan di kabupaten Pamekasan berlangsung pada musim penghujan bulan Desember 2016. Strategi eksplorasi ditentukan oleh keberadaan tanaman indigenous di daerah sasaran berdasarkan informasi dari Dinas Pertanian setempat. Karena tanaman indigenous dapat dijumpai dalam bentuk yang dibudidayakan oleh petani setempat baik di kebun, pekarangan rumah, maka strategi eksplorasi diarahkan pada usaha identifikasi dan pencatatan tanaman contoh di kebun maupun pekarangan dan di habitat alamnya. Metode pendataan tanaman contoh dilakukan secara acak dan selektif, sehingga semua variasi yang ada di dalam tanaman dapat diwakili. Penelitian ditentukan dengan menggunakan metode purposive sampling yaitu data yang diperoleh berdasarkan wilayah yang ditentukan. Penetuan lokasi penelitian berdasarkan wilayah bagian dalam satu kabupaten dan ketinggian tempat. Penelitian dilaksanakan di beberapa kecamatan yang dipilih dengan ketinggian tempat yang berbeda, bagian utara Kabupaten Pamekasan dipilih 
Kecamatan Pasean (50 mdpl) dan kecamatan Waru (159 mdpl), bagian tengah dipilih kecamatan Pakong (250 mdpl) dan kecamatan Kadur (140 mdpl), dan bagian selatan dipilih kecamatan Pademawu (7 mdpl) dan kecamatan Tlanakan (22 mdpl) (BPS Pamekasan, 2015). Pengambilan sampel dilakukan secara acak sebanyak 12 titik sampel setiap Kecamatan dengan teknik eksplorasi. Strategi eksplorasi diarahkan pada usaha pengambilan sampel di kebun maupun pekarangan dan di habitat alamnya, sehingga semua variasi tanaman dapat diwakili (Putrasamedja, 2005). Pendataan tanaman sayuran berdasarkan pada pemanfaatan bagian tanaman yang diketahui melalui observasi juga wawancara dengan masyarakat sekitar lokasi titik sampel. Pemanfaatan yang dimaksud adalah bagian tanaman yang dapat dikonsumsi seperti daun, batang, bunga, buah, biji, umbi dan bagian lain.

\section{HASIL DAN PEMBAHASAN}

Sayuran indigenous biasanya tumbuh di pekarangan rumah maupun kebun secara alami dan dimanfaatkan untuk kepentingan keluarga, baik sebagai sayuran yang dimasak maupun lalapan. Pada kenyataannya di daerah Pamekasan sayuran indigenous belum memasuki pasar dan hanya digunakan sebagai lalap untuk konsumsi keluarga petani. Banyak sayuran indigenous yang berfungsi sebagai obat. Sayuran indigenous dapat dicontohkan seperti: kemangi (dimanfaatkan daunnya sebagai lalapan), kenikir (dimanfaatkan daunnya sebagai lalapan), katuk (dimanfaatkan daunnya sebagai bahan sayur dan lalapan), turi (dimanfaatkan tunas daun, bunga dan buahnya sebagai bahan sayur), beluntas (dimanfaatkan daunnya sebagai bahan sayur). Petani dengan lahan yang sempit (kurang dari 1 ha) umumnya menanami lahannya dengan tanaman sayuran semusim dan tanaman tahunan (Roshetko et al., 2012). Tanaman sayuran dari hasil eksplorasi di Kabupaten Pamekasan ditemukan sebanyak 39 jenis sayuran seperti pada Tabel 1.

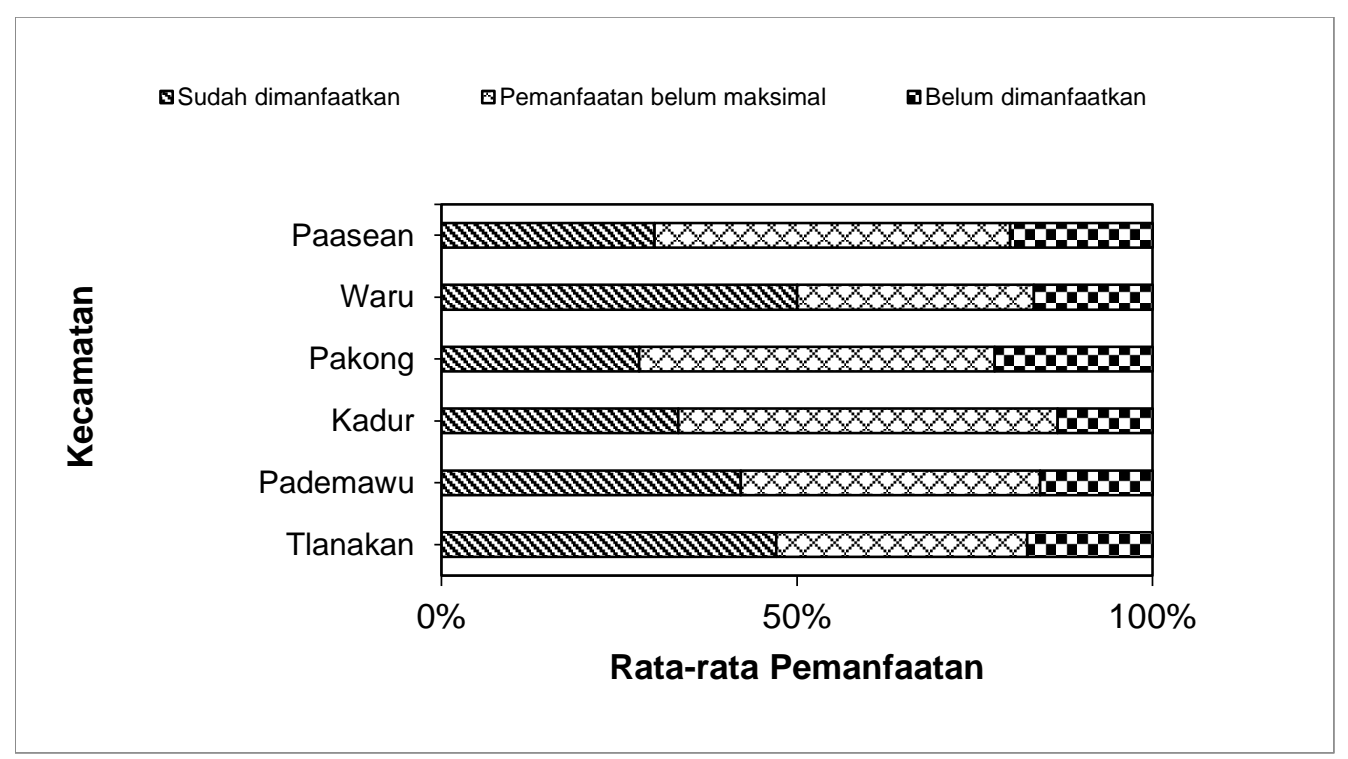

Gambar 1. Nilai rata-rata pemanfaatan tanaman di Kabupaten Pamekasan 
Tabel 1. Tanaman dan pemanfaatan bagian tanaman di Kabupaten Sumenep

\begin{tabular}{|c|c|c|c|c|c|c|c|c|c|}
\hline \multirow{2}{*}{ No } & \multirow{2}{*}{ Nama Botani } & \multirow{2}{*}{$\begin{array}{c}\text { Nama Indonesia / } \\
\text { Madura }\end{array}$} & \multicolumn{7}{|c|}{ Bagian yang Dapat Dimanfaatkan } \\
\hline & & & Tunas & Daun & Batang & Bunga & Buah & $\mathrm{Biji}$ & Umbi \\
\hline 1 & $\begin{array}{l}\text { Sesbania } \\
\text { grandiflora L. }\end{array}$ & $\begin{array}{l}\text { Turi } \\
\text { Toroi }\end{array}$ & $\sqrt{ }$ & & & $\sqrt{ }$ & $\sqrt{ }$ & & \\
\hline 2 & $\begin{array}{l}\text { Vigna radiata } \\
\text { L.R. Wilczek }\end{array}$ & $\begin{array}{l}\text { Kacang hijau } \\
\text { Arta' }\end{array}$ & & & & & & $\sqrt{ }$ & \\
\hline 3 & $\begin{array}{l}\text { Musa } \\
\text { paradisiaca } \\
\text { var }\end{array}$ & $\begin{array}{l}\text { Pisang } \\
\text { Keddhang }\end{array}$ & & & $\sqrt{ }$ & $\sqrt{ }$ & & & \\
\hline 4 & $\begin{array}{l}\text { Artocarpus } \\
\text { heterophyllus } \\
\text { L. }\end{array}$ & $\begin{array}{l}\text { Nangka } \\
\text { Nangka }\end{array}$ & & & & & $\sqrt{ }$ & & \\
\hline 5 & $\begin{array}{l}\text { Pluchea indica } \\
\text { L. }\end{array}$ & $\begin{array}{l}\text { Beluntas } \\
\text { Bluntas }\end{array}$ & & $\sqrt{ }$ & & & & & \\
\hline 6 & $\begin{array}{l}\text { Leucawna } \\
\text { luecocephala } \\
\text { lamk }\end{array}$ & $\begin{array}{l}\text { Lamtoro } \\
\text { Plandingan }\end{array}$ & & & & & & $\sqrt{ }$ & \\
\hline 7 & $\begin{array}{l}\text { Ipomoea } \\
\text { batatas L. }\end{array}$ & $\begin{array}{l}\text { Ubi jalar } \\
\text { Tela }\end{array}$ & & $\sqrt{ }$ & & & & & \\
\hline 8 & $\begin{array}{l}\text { Manihot } \\
\text { esculenta } \\
\text { Crantz }\end{array}$ & $\begin{array}{l}\text { Singkong } \\
\text { Tenggâng/Sabbhr } \\
\text { âng }\end{array}$ & & $\sqrt{ }$ & & & & & \\
\hline 9 & $\begin{array}{l}\text { Vigna } \\
\text { unguiculata } \\
\text { sesquipedalis }\end{array}$ & $\begin{array}{l}\text { Kacang panjang } \\
\text { Oto' }\end{array}$ & & $\sqrt{ }$ & & & $\sqrt{ }$ & & \\
\hline 10 & $\begin{array}{l}\text { Ipomoea } \\
\text { aquatica } \\
\text { Forssk. }\end{array}$ & $\begin{array}{l}\text { Kangkung } \\
\text { Kangkong }\end{array}$ & & $\sqrt{ }$ & $\sqrt{ }$ & & & & \\
\hline 11 & $\begin{array}{l}\text { Solanum } \\
\text { melongena L. }\end{array}$ & $\begin{array}{l}\text { Terung } \\
\text { Terrong }\end{array}$ & & & & & $\sqrt{ }$ & & \\
\hline 12 & $\begin{array}{l}\text { Artocarpus } \\
\text { camansi L. }\end{array}$ & $\begin{array}{l}\text { Kluwih } \\
\text { Kolor }\end{array}$ & & & & & $\sqrt{ }$ & & \\
\hline 13 & $\begin{array}{l}\text { Capsicum } \\
\text { frustescens } \mathrm{L} .\end{array}$ & $\begin{array}{l}\text { Cabai rawit } \\
\text { Cabbhi lete' }\end{array}$ & & & & & $\sqrt{ }$ & & \\
\hline 14 & Bambusa sp. & $\begin{array}{l}\text { Bambu } \\
\text { Perreng }\end{array}$ & $\sqrt{ }$ & & & & & & \\
\hline 15 & $\begin{array}{l}\text { Allium } \\
\text { ampeloprasu } \\
m \mathrm{~L} .\end{array}$ & $\begin{array}{l}\text { Bawang prei } \\
\text { Bhâbâng pri }\end{array}$ & & $\sqrt{ }$ & & & & & \\
\hline 16 & $\begin{array}{l}\text { Luffa } \\
\text { Acutangula L. } \\
\text { Roxb }\end{array}$ & $\begin{array}{l}\text { Gambas } \\
\text { Langker }\end{array}$ & & & & & $\sqrt{ }$ & & \\
\hline 17 & $\begin{array}{l}\text { Phaseolus } \\
\text { lunatus L. }\end{array}$ & $\begin{array}{l}\text { Kacang koro } \\
\text { Krato' }\end{array}$ & & & & & & $\sqrt{ }$ & \\
\hline 18 & $\begin{array}{l}\text { Moringa } \\
\text { oleifera L. }\end{array}$ & $\begin{array}{l}\text { Kelor } \\
\text { Marongghi }\end{array}$ & & $\sqrt{ }$ & & & & & \\
\hline 19 & $\begin{array}{l}\text { Carica papaya } \\
\text { L. }\end{array}$ & $\begin{array}{l}\text { Pepaya } \\
\text { Kates }\end{array}$ & & $\sqrt{ }$ & & $\sqrt{ }$ & $\sqrt{ }$ & & \\
\hline 20 & $\begin{array}{l}\text { Cucumis } \\
\text { sativus L. }\end{array}$ & $\begin{array}{l}\text { Mentimun } \\
\text { Temon }\end{array}$ & & & & & $\sqrt{ }$ & & \\
\hline 21 & $\begin{array}{l}\text { Capsicum } \\
\text { annum L. }\end{array}$ & $\begin{array}{l}\text { Cabai merah } \\
\text { Cabbhi mera }\end{array}$ & & & & & $\sqrt{ }$ & & \\
\hline 22 & $\begin{array}{l}\text { Artocarpus } \\
\text { altilis Fosberg }\end{array}$ & $\begin{array}{l}\text { Sukun } \\
\text { Sokon }\end{array}$ & & & & & $\sqrt{ }$ & & \\
\hline 23 & $\begin{array}{l}\text { Colocasia } \\
\text { esculenta L. } \\
\text { Schott }\end{array}$ & $\begin{array}{l}\text { Keladi } \\
\text { Kombhâ }\end{array}$ & & & $\sqrt{ }$ & & & & $\sqrt{ }$ \\
\hline 24 & $\begin{array}{l}\text { Polyscias } \\
\text { scutellaria } \\
\text { Burm.f. } \\
\text { Fosberg }\end{array}$ & $\begin{array}{l}\text { Mangkokan putih } \\
\text { Ko'-mangko'an }\end{array}$ & & $\sqrt{ }$ & & & & & \\
\hline 25 & $\begin{array}{l}\text { Solanum } \\
\text { ficifolium } \\
\text { Ortega }\end{array}$ & $\begin{array}{l}\text { Takokak } \\
\text { Poka' }\end{array}$ & & & & & $\sqrt{ }$ & & \\
\hline 26 & $\begin{array}{l}\text { Sauropus } \\
\text { androgynus L. }\end{array}$ & $\begin{array}{l}\text { Katuk } \\
\text { Ghâraghâr }\end{array}$ & & $\sqrt{ }$ & & & & & \\
\hline
\end{tabular}




\begin{tabular}{|c|c|c|c|c|c|c|c|c|c|}
\hline \multirow{2}{*}{ No } & \multirow{2}{*}{ Nama Botani } & \multirow{2}{*}{$\begin{array}{c}\text { Nama Indonesia / } \\
\text { Madura }\end{array}$} & \multicolumn{7}{|c|}{ Bagian yang Dapat Dimanfaatkan } \\
\hline & & & Tunas & Daun & Batang & Bunga & Buah & Biji & Umbi \\
\hline 27 & $\begin{array}{l}\text { Parkia } \\
\text { speciosa L. }\end{array}$ & $\begin{array}{l}\text { Petai } \\
\text { Pete }\end{array}$ & & & & & $\sqrt{ }$ & & \\
\hline 28 & $\begin{array}{l}\text { Cucurbita } \\
\text { moschata } \\
\text { Duch }\end{array}$ & $\begin{array}{l}\text { Labu kuning } \\
\text { Labu Koneng }\end{array}$ & & $\sqrt{ }$ & & & $\sqrt{ }$ & & \\
\hline 29 & $\begin{array}{l}\text { Sechium } \\
\text { edule Jacq. } \\
\text { Swartz }\end{array}$ & $\begin{array}{l}\text { Labu siam } \\
\text { Labu Siem }\end{array}$ & & & & & $\sqrt{ }$ & & \\
\hline 30 & $\begin{array}{l}\text { Phaseolus } \\
\text { Vulgaris } \mathrm{L} \text {. } \\
\text { Allium cepa }\end{array}$ & $\begin{array}{l}\text { Buncis } \\
\text { Buncis }\end{array}$ & & & & & $\sqrt{ }$ & & \\
\hline 31 & $\begin{array}{l}\text { var } \\
\text { ascalonnicum } \\
\text { L. }\end{array}$ & $\begin{array}{l}\text { Bawang merah } \\
\text { Bhâbâng mera }\end{array}$ & & & & & & & $\sqrt{ }$ \\
\hline 32 & $\begin{array}{l}\text { Amaranthus } \\
\text { spinosus L. }\end{array}$ & $\begin{array}{l}\text { Bayam } \\
\text { Tarnya' }\end{array}$ & & $\sqrt{ }$ & $\sqrt{ }$ & & & & \\
\hline 33 & $\begin{array}{l}\text { Averrhoa } \\
\text { bilimbi L. }\end{array}$ & $\begin{array}{l}\text { Belimbing wuluh } \\
\text { Bhâlimbhing bulu }\end{array}$ & & & & & $\sqrt{ }$ & & \\
\hline 34 & $\begin{array}{l}\text { Etlingera } \\
\text { elatior Jack } \\
\text { R.M. Smith }\end{array}$ & $\begin{array}{l}\text { Kecombrang } \\
\text { Kacombhrâng }\end{array}$ & & & & $\checkmark$ & & & \\
\hline 35 & $\begin{array}{l}\text { Lycopersicon } \\
\text { esculentum }\end{array}$ & $\begin{array}{l}\text { Tomat } \\
\text { Tomat/Ranti }\end{array}$ & & & & & $\sqrt{ }$ & & \\
\hline 36 & $\begin{array}{l}\text { Anacardium } \\
\text { occidentale L. }\end{array}$ & $\begin{array}{l}\text { Jambu mete } \\
\text { Jâmbhu Monyet }\end{array}$ & & $\checkmark$ & & & & & \\
\hline 37 & $\begin{array}{l}\text { Paederia } \\
\text { scandens } \mathrm{L} \text {. }\end{array}$ & $\begin{array}{l}\text { Sembukan } \\
\text { Kasembhugan / } \\
\text { Daun to'-kentoan }\end{array}$ & & $\checkmark$ & & & & & \\
\hline 38 & $\begin{array}{l}\text { Morinda } \\
\text { citrifolia L. }\end{array}$ & $\begin{array}{l}\text { Mengkudu } \\
\text { Pace / Koddhu' }\end{array}$ & & $\sqrt{ }$ & & & & & \\
\hline 39 & Ocimum sp. & $\begin{array}{l}\text { Kemangi } \\
\text { Komange }\end{array}$ & & $\sqrt{ }$ & & & & & \\
\hline
\end{tabular}

Di wilayah Pamekasan bagian Selatan survey dilakukan di kecamatan Tlanakan dan Pademawu. Sebanyak 17 komoditi ditemukan Kecamatan Tlanakan, 8 komoditi (47.1\%, Gambar 1), sudah dimanfaatkan antara lain: singkong, gambas, cabai rawit, terung, mentimun, kacang panjang, kangkung dan cabai merah; 6 komoditi (35.3\%) pemanfaatan tanaman belum maksimal antara lain: turi, lamtoro, beluntas, pepaya bambu dan sukun; dan ada 3 komoditi $(17.6 \%)$ yang masih belum dimanfaatkan yaitu: ubi jalar, pisang dan keladi. Di Kecamatan Pademawu ditemukan sebanyak 19 komoditi, dengan rincian 8 komoditi (42.1\%) sudah dimanfaatkan antara lain: gambas, cabai rawit, terung. kluwih, bawang prei, kacang panjang, kangkung dan kacang hijau; sebanyak 8 komoditi (42.1\%) pemanfaatan belum maksimal antara lain: kelor, singkong, turi, lamtoro, beluntas, nangka, kacang koro dan pepaya; dan sisanya 3 komoditi (15.8\%) belum dimanfaatkan adalah ubi jalar, pisang dan bambu. Beberapa komoditi hanya ditemukan di Kecamatan Tlanakan seperti: mentimun, keladi dan sukun, sedangkan komoditi yang hanya ditemukan di Kecamatan Pademawu seperti: kelor, nangka, kacang koro, kluwih, bawang prei dan kacang hijau. Ada 2 komoditi yang pemanfaatannya berbeda dari 2 Kecamatan tersebut, pertama, tanaman singkong di Kecamatan Tlanakan daunnya sudah dimanfaatkan dan dijual di pasar, sedangkan di Kecamatan Pademawu masih belum dijual di pasar hanya dimanfaatkan sendiri. Kedua, tunas tanaman bambu di Kecamatan Tlanakan sudah digunakan untuk dijadikan sayur, sedangkan di Kecamatan Pademawu tidak ada yang menggunakan bambu untuk sayur. 
Di kecamatan Kadur ditemukan sebanyak 15 komoditi, dengan rincian sebanyak 5 komoditi (33.3\%) sudah dimanfaatkan antara lain: gambas, cabai rawit, terung, kacang panjang dan kacang hijau dengan persentase; 8 komoditi $(53.3 \%)$ pemanfaatan belum maksimal antara lain: kelor, singkong, turi, beluntas, nangka, kacang koro, pepaya dan sukun; dan sisanya 2 komoditi (13.3\%) belum dimanfaatkan yaitu pisang dan mangkokan putih. Hasil survei di Kecamatan Pakong ditemukan sebanyak 18 komoditi, dengan rincian sebanyak 5 komoditi (27.8\%) sudah dimanfaatkan antara lain: cabai rawit, petai, labu siam, mentimun dan kacang panjang; sebanyak 9 komoditi (50\%) pemanfaatan belum maksimal antara lain: kelor, singkong, turi, beluntas, kacang koro, takokak, pepaya, sukun dan katuk; dan sisanya 4 komoditi $(22.2 \%)$ belum dimanfaatkan adalah pisang, labu kuning, keladi dan ubi jalar. Beberapa komoditi hanya ditemukan di Kecamatan Kadur seperti: gambas, nangka, mangkokan putih dan kacang hijau, sedangkan beberapa komoditi yang hanya ditemukan di Kecamatan Pakong seperti: labu kuning, ubi jalar, katuk, takokak, petai, labu siam, mentimun dan keladi. Mertz (1999) melaporkan bahwa nilai ekonomi dari komoditi sayuran akan mempengaruhi potensi penanaman, artinya ketika komoditas sayuran harganya murah maka usaha pengembangannya tidak banyak dilakukan.

Hasil survei di Kecamatan Waru ditemukan sebanyak 24 komoditi, dimana sebanyak 12 komoditi (50\%, Gambar 1) sudah dimanfaatkan, antara lain: gambas, labu kuning, cabai rawit, terung, kacang koro, bawang merah, bayam, buncis, mentimun, kacang panjang, tomat dan kangkung; sebanyak 8 komoditi (33.3\%) sudah dimanfaatkan tetapi belum maksimal, antara lain: kelor, singkong, turi, belimbing wuluh, beluntas, nangka, pepaya dan sukun; dan sisanya sebanyak 4 komoditi
(16.7\%) belum dimanfaatkan yaitu tanaman pisang, bambu, keladi dan kecombrang. Hasil survei di Kecamatan Pasean ditemukan sebanyak 20 komoditi, dengan rincian sebanyak 6 komoditi (30\%, Gambar 1) sudah dimanfaatkan antara lain: gambas, labu kuning, cabai rawit, terung, bawang merah dan bayam; sebanyak 10 komoditi $(50 \%)$ pemanfaatan belum maksimal antara lain: kelor, singkong, turi, jambu mete, lamtoro, belimbing wuluh, beluntas, nangka, katuk dan kemangi; dan sisanya sebanyak 4 komoditi $(20 \%)$ belum dimanfaatkan antara lain pisang, sembukan, ubi jalar, dan mengkudu. Beberapa komoditi hanya ditemukan di Kecamatan Waru seperti: kacang koro, pepaya, bambu, buncis, mentimun, kacang panjang, keladi, kecombrang, tomat, sukun, dan kangkung, sedangkan tanaman yang hanya ditemukan di Kecamatan Pasean adalah tanaman jambu mete, lamtoro, ubi jalar, sembukan, mengkudu, katuk, dan kemangi. Usaha budidaya pertanian di Kabupaten Pamekasan dilakukan dalam usaha pemenuhan kebutuhan keluarganya, sedikit sekali yang berorientasi dijual ke pasar (Setiawan, 2009). Tingginya persentase tanaman yang belum dimanfaatkan dan pemanfaatan tanaman yang belum maksimal menjadi perhatian yang serius untuk mendorong masyarakat supaya konsumsi buah lebih banyak lagi. Konsumsi sayuran dapat meningkatkan kesehatan masyarakat dan mengurangi resiko beberapa penyakit seperti cardiovascular, stroke, arthritis, dan kanker (Andarwulan et al., 2012).

Dari pegamatan di lapang, terdapat beberapa jenis sayuran indigenous yang mempunyai potensi untuk dikembangkan seperti katuk, kemangi, dan turi. Sayuran tersebut selain dimanfaatkan sebagai sayuran, tanamannya mempunyai ketahanan terhadap kekeringan. Pemanfaatan sayuran indigenous dan nilai ekonominya dari masing-masing daerah 
(kecamatan) berbeda-beda. Banyak petani yang menanam sayuran tetapi tidak punya akses ke pasar karena keterbatasan informasi dan saluran pemasaran (Roshetko et al., 2012). Hal ini, dipengaruhi oleh tingkat kesukaan petani dalam menanam, ketersediaan bahan tanam serta kemampuan adaptasi tanaman terhadap kondisi tanah daerah setempat. Di Pulau Madura produksi tanaman sayuran sangat terbatas karena kondisi tanah yang kering. Pohon turi (Sesbania grandiflora L.) yang ditanam sebagai pembatas tegalan dan sawah di Madura berpotensi untuk dioptimalkan sebagai sumber bahan sayuran yang kaya dengan kandungan flavonoid (Bhoumik et al., 2016). Oleh kerena itu, sayuran indigenous mempunyai peranan untuk membantu mengatasi masalahmasalah kekurangan vitamin dan gizi, disamping protein bagi penduduk terutama bagi keluarga prasejahtera. Banyak tanaman sayuran di atas mempunyai kandungan obat seperti antimikroba, flavonoid serta serat (Krasaekoopt and Kongkarnchanatip, 2005; Zarkani, 2016). Flavonoid adalah komponen penting yang terdapat pada bunga turi, berperan dalam aktivitas penghambatan mikroba (Arunabha and Satish, 2014), selain itu turi juga mengandung tanin dan beberapa nutrisi serta astringent alami (Vinothini et al., 2017).

Tanaman ada yang ditanam secara monokultur di tempat terbuka, ada pula yang ditanam tumpangsari dibawah tegakan pohon tahunan (Setiawan, 2013). Manurung et al. (2008) melaporkan beberapa tanaman dapat tumbuh baik dibawah tegakan seperti honje (Etlingera elatior), katuk (Sauropus androgynus (L.) Merrill), kenikir (Cosmos caudatus Kunth), kangkong (Ipomoea aquatica Forsskal), bayam (Amaranthus sp.), cabai (Capsicum annuum L.), terong (Solanum melongena L.), kacang panjang (Vigna unguiculata (L.) Walp.), kacang hijau (Phaseolus vulgaris L.) dan tomato (Lycopersicon esculentum Miller). Di Pamekasan tanaman turi banyak ditanam di pekarangan serta pematang utamanya sebagai pembatas tanah di sawah dan tegalan. Bagian tanaman turi seperti daun, bunga dan kacang selain sebagai sayuran juga sumber bahan baku obat anemia, batuk, penurun panas, sebagai stimulasi kecerdasan, dan di Jawa biasa dipakai sebagai obat lambung (Kumar et al., 2008). Turi mudah diperbanyak dengan biji dan stek (Mardhiyetti et al., 2014). Tanaman di atas dapat diandalkan mengingat tanaman tersebut telah beradaptasi terhadap lingkungan setempat dan cara budidayanya mudah dan murah.

\section{SIMPULAN}

Pemanfaatan komoditi tanaman sayuran di Kabupaten Pamekasan masih beragam dan belum maksimal, tanaman sayuran sudah dimafaatkan oleh masyarakat tertinggi pada Kecamatan Waru (50\%), Kecamatan Tlanakan (47.1\%) dan Kecamatan Pademawu (42.1\%), sedangkan komoditi yang pemanfaatan belum maksimal terjadi pada Kecamatan Kadur (53.3\%), Kecamatan Pakong dan Kecamatan Pasean (50\%). Komoditi yang belum dimanfaatkan terbanyak ada di Kecamatan Pakong (22.2\%) dan Kecamatan Pasean (20\%). Perlu pendampingan kepada masyarakat Kabupaten Pamekasan terkait pengetahuan dan pemanfaatan tentang sayuran lokal. 


\section{DAFTAR PUSTAKA}

Andarwulan, N., D. Kurniasih, R. Aris, H. Rahmat, A. V. Roto, B.W. Bolling. 2012. Polyphenols, carotenoids, and ascorbic acid in underutilized medicinal vegetables. J. Funct. Foods 4(1): 339-347.

Arunabha, M., N. Satish. 2014. Evaluation of immunomodulatory activity of Sesbania grandiflora flowers extract in mice. Indones. J. Pharm. 25(4): 277-283.

Bhoumik, D., A.H. Berhe, A. Mallik. 2016. Evaluation of gastric anti-ulcer potency of ethanolic extract of Sesbania grandiflora Linn leaves in experimental animals. Am. J. Phytomedicine Clin. Ther. 4(6): 174-182.

BPS Pamekasan. 2015. Tinggi dari permukaan laut dan luas wilayah menurut kecamatan.

Krasaekoopt, W., A. Kongkarnchanatip. 2005. Anti-microbial properties of Thai traditional flower vegetable extracts. AU J.T. 9(2): 71-74.

Kumar, A.S., K. Venkateshwaran, S. Vanitha, M. Ganesh, M. Vasudevan, T. Sivakumar. 2008. Synergism between methanolic extract of Sesbania grandiflora (Fabaceae) flowers and oxytetracycline.

Pharmacologyonline 3: 6-11.

Manurung, G., A.D. Susila, J. Roshetko, M.C. Palada. 2008. Findings and challenges: can vegetables be productive under tree shade management in West Java?. SANREM -TMPEGS Publication.

Mardhiyetti, Z. Syarif, N. Jamarun, I. Suliansyah. 2014. Response same explant of turi (Sesbania grandiflora) in shoot induction medium. Int. J. Advaced Sci. Eng. Inf. Technol. 4(4): 30-32.

Mertz, O. 1999. Preliminary study on the cultivation potential of wild vegetables Etlingera elatior, $\mathrm{E}$. punicea and Commelina paludosa of Sarawak. J. Trop. Agric. Fd. Sc. 27(1): 27-37.

Putrasamedja, S. 2005. Eksplorasi dan koleksi sayuran indigenous di Kabupaten Karawang. Bul. Plasma Nutfah 11(1): 16-20.

Roshetko, J.M., G.S. Manurung, I. Kurniawan, L. Dahlia, A. Susila. 2012. Intensifying vegetable production in smallholder agroforestry systems in West Java. In Acta Hort. (Vol. 958, pp. 59-66).

Santosa, E., U. Prawati, Sobir, Y. Mine, N. Sugiyama. 2015. Agronomy, utilization and economics of indigenous vegetables in West Java, Indonesia. J. Hort. Indones. 6(3): 125-134.

Setiawan, E. 2009. Kearifan lokal pola tanam tumpangsari di Jawa Timur. Agrovigor 2(2): 79-89.

Setiawan, E. 2013. The local wisdom by farmer in East Java: utilization of cultivated plant in intercropping system. J. Rekayasa 6(2): 67-76.

Vinothini, K., M.S. Devi, V. Shalini, S. Sekar, R.B. Semwal, P. Arjun, D.K. Semwal. 2017. In vitro micropropagation, total phenolic content and comparative antioxidant activity of different extracts of Sesbania grandiflora (L.) Pers. Curr. Sci. 113(6): 11421147.

Zarkani, A.A. 2016. Antimicrobial activity of Hibiscus sabdariffa and Sesbania grandiflora extracts against some $\mathrm{G}-\mathrm{ve}$ and $\mathrm{G}+\mathrm{ve}$ strains. Banat. J. Biotechnol. 7(13): 17-23. 